\title{
Derrida's Turn to Franciscan Philosophy
}

\author{
Marko Zlomislic \\ "Taste and see that the Lord is good." - Psalm 34 \\ And you tell me, friends, that there is no disputing taste \\ and tasting? But all life is a dispute over taste and \\ tasting! - Friedrich Nietasche, \\ (Thus Spoke Zarathustra)
}

\begin{abstract}
ontemporary French philosophers such as Levinas, Bataille, and Derrida, along with the existentialists Kierkegaard and Nietzsche have all made use of Franciscan insights in order to safeguard the ipseity that cannot be reduced or totalized. ${ }^{1}$ In keeping with the taste that concerns me, this paper will examine Derrida's turn to the poetry of Gerard Manley Hopkins and how such a turn may place Derrida within a catholic and Franciscan tradition.
\end{abstract}

\section{Tasting the Responsible Person}

To explore the being of the person who is responsible and says "I" Derrida turns to the poetic insights of Gerard Manley Hopkins. Derrida asks, "what taste could this $j e$, this I have?" and "what does it mean for an I to feel itself" 2 By turning to Hopkins's notion of Selftaste, Derrida shows how the responsible person is affected by the scope and scape of ipseity. While Hopkins's poetry is said to deal with nature and its landscape the primary focus given Hopkins's Catholicism is on the person and how this person tastes, feels, touches and senses the various scapes and inscapes of haecceity in all things.

Derrida writes,

In Hopkins extraordinary lexicon, what comes to effect, identify, think, proves this selfhood, in truth that by which selfhood affirms, affects itself, "selves" itself operates on its own selving as Hopkins will say is not thought, consciousness or reflection but taste. ${ }^{3}$

\footnotetext{
${ }^{1}$ I am currently writing a book entitled Franciscan Postmodernity.

2 Jacques Derrida, "Justices," Critical Inquiry, 31 (Spring 2005). Hereafter cited as Justices.

${ }^{3}$ Ibid., 698.
} 


\section{DERRIDA'S TURN}

Taste from the Latin gusto is the faculty by which a flavour of a thing is discerned. Gusto relates to the Sanskrit word jus, which means enjoy and be pleased. Close to St. Francis, Hopkins not only tastes the landscape but all the inscapes of being human that range from joy to deep despair. Selftaste can have no final assessment because its worth is without price and beyond the cost of calculative accounting. This Selftaste to follow Derrida is priceless (san prix). "What is absolutely precious, the other in his or her own dignity, has no price.... every one is worth as much as the other, precisely beyond all value: priceless." 4

The question of taste for Derrida engages the issue of the cannibalism within mourning; how the other is incorporated, remembered, retained in the crypt of memory; bound together in what Kierkegaard in Works of Love calls "the kinship of death." 5 The crypt as Derrida reminds us in Glas, "organizes the ground to which it does not belong." "While it will always be possible to taste the thing, the taste of the thing never yields its Selftaste. Even when one says, "I love the way you taste," Selftaste remains elusive and cannot be caught or contained by the palate.

Related to the word flavor is the word smolder. Smolder means to burn and smoke without flame. We can taste this smolder in the fall, in the decay and excretion of things, in the spring when the freshness of flowers, trees, grass and green boils over the landscape. Hopkins will write,

The world is charged with the grandeur of God.

It will flame out, like shining from shook foil. ${ }^{7}$

While the natural world according to Hopkins, “wears man's smudge and shares man's smell, the flavor can never be exhausted for "there lives the dearest freshness deep down things." In "Pied Beauty" Hopkins raises the issue of responsibility when he declares "all things counter, original, spare, strange." Spare from the Old English sparian means to refrain from harming, to allow to go free. Strange means alien, foreign, from elsewhere, unknown and unfamiliar and unique. We are close and yet strange to ourselves. We are strangers to our own uniqueness or haecceity that flows forth in excess that cannot be contained.

The Franciscan philosophers: Bonaventure, Scotus and Ockham became nominalists in order to safeguard each single individual from the power

\footnotetext{
4 Jacques Derrida, "On the Priceless" in Negotiations, ed. and trans. by Elizabeth Rottenburg (Stanford: Stanford University Press), 324-325. Hereafter cited as N.

5 Soren Kierkegaard, Works of Love, trans. by Howard and Edna Hong (New York: Harper, 1962), 317. Kierkegaard continues, "I know of no better way to describe true memory than by this weeping softly...No, one must remember the dead; weep softly, but grieve long." 319. Hereafter cited as WOL.

${ }^{6}$ Jacques Derrida, Glas, trans. by John P. Leavey, Jr., and Richard Rand (Lincoln: University of Nebraska Press, 1986), 166.

${ }^{7}$ Gerard Manley Hopkins, "God's Grandeur."

${ }^{8}$ Ibid.
} 
of totalization. Bonaventure was enthralled by the great diversity of creation and to the praised the unlimited possibilities that happen in the radical leap of the new. St. Francis who imitated Jesus realized that God could be found in the inner being of all flesh. Following the Franciscans, Hopkins was inspired to find a new significance to flesh. The inscape for Hopkins bears the stamp of the divine. Each mortal thing offers itself as a witness to the splendor of God.

Vigilance calls us to protect the person bound in a bond of singularities, by not harming, by guarding freedom so as not to reduce the person to a force ${ }^{9}$ or a maker of systems. ${ }^{10}$ To protect the uniqueness of persons Derrida will argue that we cannot be satisfied with a neutral and conceptual analysis that reduces the difficulty of our situation, which is ultimately irreducible. Such systems deal with homogenization and calculability and "close themselves off from this coming of the other." 11 If we take seriously the uniqueness of each Self, which according to Kierkegaard is "a work of the most faithful love,"12 then we are necessarily involved in an excessive responsibility of which we cannot be absolved not even in the moment of death where according to Kierkegaard "all ways meet."13

The various flavors of nature are meant to provide an awakening so that the fading fire of the Self can be mended. In Hopkins's words from his poem "The Candle Indoors,"

Come you indoors, come home; your fading fire Mend first and vital candle in close heart's vault.

Is our taste so bleared and smeared that it requires mending with the help of salt? Salt is that which gives life or pungency. The pungent is what is sharp and poignant. Death is such a point. Once we realize that it is for the Self that we mourn how do we overcome the finality that "it is the blight man was born for"14? In Derrida's words from a beautiful essay that analyses the works of Gadamer and Celan we read,

For every time, and every time singularly, every time irreplaceably, every time infinitely, death is nothing less than an end of the world. Not only one end among others, the end of someone or of something in the world...death marks every time, every time in defiance of arithmetic, the absolute end of the one and only world, of which everyone opens as one and the only world, the end of the

\footnotetext{
${ }^{9}$ For example in the work of Gilles Deleuze.

${ }^{10}$ For example in the work of Niklas Luhmann

$11 \mathrm{~N}, 182$.

12 WOL, 317.

13 WOL, 317.

${ }^{14}$ Gerard Manley Hopkins, "Spring and Fall: To a Young Child."
} 
unique world .... for an unique living being, be it human or not. ${ }^{15}$

Following Hopkins, we can ask how things in the world touch us, seize us, and take possession of us as we seek, visit, inquire and pursue what beseeches us. The Latin tactus relates to the word tangent. Tangent is a meeting point. It is the point at which responsibility is engaged or ignored as the Self meets/meats itself and others in a singularity and uniqueness that cannot be leveled off. In Hopkins words,

I consider my selfbeing, my consciousness and feeling of myself, that taste of myself of I and me above and in all things is more distinctive than the taste of ale or alum, more distinctive that the smell of walnutleaf or camphor and is incommunicable by any means to another man. ${ }^{16}$

Though incommunicable by any means to another person, we nonetheless attempt to communicate. Though Selftaste cannot be communicated through lips, mouth and tongue, it can be witnessed.

Is this communication of what is incommunicable and yet witnessed, called the poetry of faith? Hopkins used unusual combinations of words, unusual word order and sprung rhythm in an attempt to explode out of traditional poetic confines. The poem attempts to testify Selftaste. The poem testifies but not in the order of cognitive reason. Hopkins poetry, following St. Augustine's formulation veritatem facere does the truth by attempting to be a testimony of love. In Derrida's words, "this love is "without jealousy that would allow the other to be." 17 The poem reveals the instress of Selftaste, which is the energy that creates and sustains the 'inscape' of the person.

\section{Naming the Unnamable}

Is Hopkins expressing a mystical principle that eludes rational and empirical analysis? Leibniz argues, "the fundamental principle of reasoning is that there nothing without a reason, or, to explain the matter more distinctly, there is no truth for which a reason does not subsist."18 Reason cannot

\footnotetext{
${ }^{15}$ Jacques Derrida, "Uninterrupted Dialogue: Between Two Infinities, The Poem," in Research in Phenomenology, 34 (2004), 8.

16 The Poems and Prose of Gerard Manley Hopkins, ed. by W. H. Gardner, 1953.

17 Jacques Derrida, "Sauf le Nom," in On the Name, trans. by David Wood, et al, (Stanford: Stanford University Press, 1995), 74.

18 G.W.F. Leibniz, Philosophical Writings, "Metaphysical Consequences of the Principle of Reason:, ed. by G.H.R. Parkinson, (London: Dent, 1987), 172. In "Discourse on Metaphysics," Leibniz mentions the "individual notion or haeceitas," but he does not follow through with this insight. His strict rationalism prevents him from realizing the full implications of "thisness." In his Monadology, he writes, "Indeed, every monad must be different from every other."
} 
communicate Selftaste yet according to Hopkins Selftaste is a truth of the person's inscape. Is Selftaste the unfathomable ground of what we are?

In the Tractatus, Wittgenstein writes "that the world is my world shows itself in the fact that the limits of the language of which I alone understand means the limits of my world." In Wittgenstein's world, the solipsistic circle encloses the tongue to make it mute. However, this is not what Hopkins means by incommunicable. Can a new language be invented so that the Self can speak its taste; can express the taste of the aporetic situation? Can it name that which language cannot name, can come close to naming but never quite able to do so? Samuel Beckett's words in The Unnamable express this aporia nicely. Beckett writes,

I'm shut up, the silence is outside, outside, inside, there is nothing but here....'ll never know, in the silence you don't know, you must go on, I can't go on, I'll go on. ${ }^{19}$

Beckett expresses the aporia that provokes us. We must and we cannot but we must. For Hopkins Selftaste is ultimately known by God but if two can commune in this silence, this Selftaste can be communicated otherwise than through language. Perhaps such a thing, (if we can call it a thing) has been felt by us when face to face with a lover who astounds you on the staircase during a goodnight kiss or when you are holding your child in your arms or when you are holding a dying parent or stranger. Such a thing can never be contained within the limits of reason alone. If one really believes in the haeccitas of Scotus then the universal cannot comprehend the singular. This is what Ockham's nominalism shows us as it protects the unique name of the person and following St. Francis, protects the uniqueness of all flesh.

The Selftaste that constitutes selfhood is an auto-affection that according to Derrida "consists in touching oneself in taste of tasting oneself in Selftaste" 20 But this auto-affection can also be hetero-affection even as it is a homo-affection. Though incommunicable, this Selftaste can still be communicated in its unique strangeness of being-queer. Derrida re-writes Scotus's doctrine of "this-ness" into the formula, " to be is to be queer" 21 In Hopkins's words, "All things counter, original, spare, strange. ${ }^{22}$ The inscape of such unique self and thing requires that justice be given as we witness "each mortal thing." Following Hopkins's phrase "the just man justices" Derrida will wonder how to do justice to the person, to the specter, to all the inscapes of the Self, to memory, to mourning, to friendship and to democracy-to-come that cannot be calculated according to existing models or rules or reason and which cannot be reduced by ontology or a phenomenology of presence.

19 Samuel Beckett, The Unnamable (Into the Silence), in The Norton Anthology of English Literature, ed. by M.H. Abrams et. al. (New York: Norton, 1962), 2602-2606.

20 "Justices," 698. Here it will be necessary to return to the notion of self-taste found in the Egyptian creation myth of Amon-Ra. I thank Roland Pada for this reference.

21 "Justices," 703.

22 Gerard Manley Hopkins, "Pied Beauty." 
In Hopkins words, "when I compare myself, my being-myself with anything else whatever, all things alike, all in the same degree, rebuff me with blank unlikeness." 23 This unlikeness is another word for Derrida's differance. As Derrida writes, in "The Deconstruction of Actuality,"

The thinking of differance is also, therefore, a thinking of urgency, of what I can neither elude nor appropriate because it is other. The event, the singularity of the event- this is what differance is about ${ }^{24}$

The scape is the scenery view of the Self that is unlike all other selves. It is impossible to get out of this cape or to gather the other into a self-identity that can be mastered. To escape the inscape, to leave a pursuer with just one's cape is an impossibility here.

A further reason that Derrida appreciates Hopkins is that he is developing an ethos of taste that goes beyond the aesthetics of taste developed by Hume and Kant. Though we cannot treat these rich texts here in their entirely a few remarks will suffice for what is being attempted here.

\section{Taste Ex- Humed and Re- Kanted}

In his, Of the Delicacy of Taste and Passion Hume makes a distinction between the delicacies of passion that makes us sensitive to joys, sorrows, and the delicacy of taste, which makes us sensitive to the arts. Hume argues that the delicacy of taste improves the delicacy of passion. Passion must be remedied by taste if possible. In $O f$ the Standard of Taste, Hume attempts to show how there can be a universal recognition of greatness if there is "a proper functioning of taste."

Our taste functions properly if our conclusions are consistent with the experiences of other nations and ages. The way in which taste is developed is through practice or by observing many works of art and making comparisons. Taste is perfected once it is free of prejudice. Hume further claims that "the general principles of taste are uniform in human nature" though he acknowledges the variations in how taste is applied. Given Hume's "academic" and "skeptical" philosophy, there is no room for justification of substance and of selfhood. Hume would dismiss the issues that Hopkins and Derrida deal with as unapproachable. ${ }^{25}$

23 Poems and Prose

24 N, 93.

${ }^{25}$ Here one can also mention Ayer where there is no trace of responsibility in his exclusively linguistic analysis, which constricts what it means to be human. The issues raised by Hopkins and Derrida do exist but cannot be seen by linguistic dogmatists which a self-imposed narrow perspective. I think the best example of the self-imposed and narrow perspective can be found in P.F. Strawson's Individuals: An Essay in Descriptive Metaphysics, (London: Methuen, 1959), 9. Strawson writes, "Up to a point the reliance upon a close examination of the actual use of words is the best, and indeed the only sure, way in philosophy." He goes on, "some of the themes discusses here are sufficiently general, the discussion undertaken from a certain limited 
Hume argues that a higher and more refined taste "enables us to judge of the character of mean, of composition, of genius, and of the production of nobler arts." By cultivating this taste, "we shall form juster notions of life." Hopkins does not reduce taste to sentiment. Hume's insights are very different from the Fransciscan inspired Hopkins who affirms "the just man justices." In other word, it is not a matter of cultivating a culture of taste so that we can form " juster notions of life" 26 . In this scenario, taste would be the springboard into justice. One can of course have a taste for Shakespeare and still be a serial killer or have a taste for classical music, engage in "outsourced" torture while drinking Coke Zero.

In thinking of Hume's reflections of taste and its cultivation I am reminded of the Island of Dr. Moreau where the dog-human, the canine-man does indeed recited W.B. Yeats poem The Second Coming while all the while being driven by the need to-be-canine. Taste reduced to sentiment and palate can never become a witness to Selftaste.

For Kant, the judgment of taste has a number of characteristics and combinations that seem incompatible. The judgment of taste is made from a subjective basis. For example, we take pleasure in contemplating an object or a work of art. We view Warhol's portrait of Mao, Chris Ofili's "The Holy Virgin"27 Andres Serrano's "Piss Christ"28 Jean-Michel Basquiat's "Tabac"29 and trust that others will find our taste to have a universal validity. Kant argues, "the judgment of taste is aesthetic" 30 However, this subjective judgment must have a universal validity. In other words, to call something beautiful is to demand that others find it beautiful.

Kant's problem is to explain how this combination is possible. While scholars have devoted considerable energy to dissolving this problem, I will not add to their efforts here. The problems as I see it is not a demand to take pleasure in an object or to even attend to that object. The demand is to attend to the person who cannot be placed within any kingdom of ends that would level off Selftaste into a bland and tasteless uniformity. In Kant's language

viewpoint and is by no means comprehensive." Reducing individuals to logical particulars is as unsatisfactory as it is absurd. Here we clearly see what is forfeited when there is no belief in persons. Perhaps Erasmus can offer an answer, in his Praise of Folly we read, " Pan makes everyone laugh with his hopeless efforts at singing, and the gods would rather listen to him than to the muses themselves, especially when the nectar has started to flow freely." Alternatively, from Bishop Berkeley's "Preface" to his Principles, which could also be taken as a reply to Derrida's critics. Berkeley writes that we are faced with "the hasty censures of a sort of men who are too apt to condemn an opinion before they rightly comprehend it."

${ }^{26}$ I assume Hume here means Anglo-Saxon conceptions of what constitutes a just life.

${ }^{27}$ Ofili depicts a black Madonna with dung and assorted female orifices cut out and pasted all over the canvas. He was playing with the word "holy.

28 The NEA funded Andres Serrano's photograph entitled "Piss Christ" (see Appendix). Along the same lines, the Canada Council funded Tamara Sanowar-Makham's creation; the "ultra-maxi priest," which is a vestment gown made of sanitary pads, and intended to express "the oppressive anti-female ideology of the Catholic Church."

29 1984. Acrylic and oil crayon on canvas showing a head smoking with the words "nervous system" and "filter" written on the canvas.

${ }^{30}$ Section 1 title, AK. 5:203. 


\section{DERRIDA'S TURN}

when we call an object beautiful, "we believe ourselves to be speaking with a universal voice and lay claim to the concurrence of everyone" 31

\section{Tasting with God's Tongue}

The event that perhaps unifies taste while still making it unique for each person is death. In "Countersignatures," Derrida writes, "I run to/on death. In other words, I run towards death, but also I run on death like a fuel, as an engine runs on petrol. I run on death, death is what makes me run." 32 Fuel from the Old French word fenaile means bundle of firewood. It relates to the Latin word focus or hearth. The secret of Selftaste is this fire or spark within each unique selved spark that gives us fuel and focus. ${ }^{33}$ Our Selftaste converges on Death. ${ }^{34}$ Here I can only trace the trajectory that such a reading would take. Our tongues would taste two testaments, old and new. Psalm 119 declares, "How sweet are thy words to my taste! Sweeter than honey to my mouth." 35 Luke 9 declares, "But I tell you of a truth, there be some standing here which shall not taste of death till they see the Kingdom of God." 36

What salt will bring taste back? What taste will be finally able to discern the perverse so that the verse of God can be tasted with a sweetness that surpasses honey? Is this all that is required- a simple refinement in taste; a tasting of the right words so that we shall never taste death? How do we switch our taste for his taste so that the taste of death is avoided?

As always, St. Paul will have the last word. In his Letter to the Hebrews he writes, "but we see Jesus, who was made a little lower than the angels for the suffering of death crowned with glory and honor that he by the grace of God should taste death for every man." 37 He tastes death for every Selftaste. He consumes it, swallows it completely so that no Self has to taste it. However, doesn't this imply that we can now taste it all without fear of final death? His tasting has transformed the Selftaste of our tongue by giving the Real thing back to us without its poisonous after-taste. We can taste the fruit of the other's Selftaste without fear of bad-taste. Is this what Christ's sacrifice on the cross actually gives us? In his poem "The Wreck of the Deutschland" (1875) Hopkins writes,

Let him easter in us,

\footnotetext{
31 Section 6

32 Jacques Derrida, “Countersignatures,” trans. by Mairéad Hanrahan, in Genet, Special Issue, Paragraph, 27:2 (2004), 38.

${ }^{33}$ Focus was first used by Hobbes in 1656 and meant the center of activity or energy. Kepler used it in 1604 to mean a point of convergence

34 The British poet, Ted Hughes, who was influenced by Hopkins writes the following in his poem "God Help the wolf after whom the Dogs Do Not Bark," " To sweeten his slow death and mix yourself in it.....to sugar the bitterness of his raging death" in Birthday Letters, " (London: faber and faber, 1998)

35 Psalm 119:103.

${ }^{36}$ Luke 9:27.

37 "Letter to the Hebrews"
} 
be a dayspring to the

dimness of us, be a

crimson-crested east.

Here Hopkins shows how Christ is the "Lord of Life" who sends rain to dry roots. In allowing Christ to "easter in us" Hopkins affirms that death is never a finality. Derrida will agree that death is never a finality but I do not see him calling on Christ to "easter in us" since it is too simple of a solution. For Derrida, we find ourselves on the trajectory of Selftaste without any final tasting. In Derrida's words from Signsponge (1976), his tribute to the poet Francis Ponge we read,

Thus the thing would be the other, the other-thing which gives me an order or addresses an impossible, intransigent, insatiable demand to me, without and exchange and without a transaction, without a possible contract. Without a word, without speaking to me, it addresses itself to me, to me alone in my irreplaceable singularity, in my solitude as well. ${ }^{38}$

Does not Derrida here sound like a Franciscan philosopher of the highest order who keeps the task of responsibility open; who keeps thinking with the aporia in order to avoid dogmatism? Derrida shows us the sharpness of the aporetic necessity we must follow for the sake of the other. This Selftaste announces the messianic. Derrida explains that the messianic,

can arrive at any moment, no one can see it coming, can see how it should come, or have forewarning of it. The relation to the other is the absence of horizon, of anticipation, there where the alterity of the other is an absolute surprise. If one can be prepared for an absolute surprise, then one must be prepared for the coming of the other as an absolute surprise- that is what I understand by the messianic.

The coming of the other arrives on a non-horizon, which does not mean the absence of horizon. It is where the horizon would be punctured by the other; always open and without saturation. For Hopkins, the incarnation is the fleshing of the Word. The Messiah for Hopkins pervades all things, thoughts and feelings. Perhaps it is at this point that Derrida parts ways with Christianity.

Derrida's last words were, "always prefer life and constantly affirm survival." Here Derrida shows us his taste and courage in the face of death

38 Jacques Derrida, Signsponge, trans. by Richard Rand (New York: Columbia University Press, 1984), 14. 


\section{DERRIDA'S TURN}

and disease. He shows us his taste, perhaps not for the incarnation of the God-Man but for a certain spirit of resurrection and living-on. Rather than a return to Catholic sacramental liturgy, which for some of us is no return at all, might we not follow Derrida in thinking about the other possibility; a wholly other possibility that is the faith of deconstruction? He writes,

We should speak here of the im-possible event, an impossible that is not merely impossible, that is not merely the opposite of possible, that is also the condition or chance of the possible. An im-possible that is the very experience of the possible. This means transforming the conception, or the experience or the saying of the experience of the possible and the impossible. ${ }^{39}$

For Christians the impossible has already happened. For Derrida, there can only be an event when it is not expected or predicted. He argues, "But this impossibility is not simply negative. This means that the impossible must be done. The event, if there is one, consists in doing the impossible." Derrida continues to add, "This doesn't mean that events don't occur, that there are none; what it means is that I cannot say the event in theoretical terms and I cannot pre-dict it either." 40 On the other hand, it seems as if Derrida is describing the second coming. What he says about the event sounds very similar to the words of Matthew's Gospel where we read, " No one knows about that day or hour, not even the angels in heaven, nor the Son, but only the Father...Therefore, keep watch, because you do not know on what day your Lord will come." 41 Derrida, following Bonaventure would of course add, "If the event is an event, not even the Father will know." What remains to be said?

Mute from the Old High German word mawen means to cry out. To be mute is to be unable to speak because of shock. The mute is what is felt or experienced but not expressed. A mute is one hired to attend a funeral as a mourner. Will we not one day all become mutes? Do we not already always mourn? Here we are on the verge, on the edge or border as we attempt to speak and communicate Selftaste without becoming absolutely mute. Following Hopkins, this Selftaste will always be yonder; farther removed and yet closest to us. So close that we can taste its tang- it's sharp and distinctive flavor, its point or sting. ${ }^{42}$ St. Francis kissing the leper transformed his taste. The honey-poison of the bee-sting that perhaps will not make us swell but will untie our tongue (solutio linguae) as we are detached to deliver this gift of Selftaste to the ones who both hate and love us much like Jesus on the cross refusing to taste sour wine and vinegar because his tongue had not only already

39 Jacques Derrida, “A Certain Impossible Possibility of Saying the Event," trans. by Gila Walker, in Critical Inquiry, 33 (Winter 2007), 454.

${ }^{40} \mathrm{Ibid}, 452$.

41 Gospel of Matthew, 24:44.

42 From the Old Norse word tangi-point and tunga or tongue. 
tasted the tang of death but had always tasted the inscape of his Father and the landscape of the kingdom come flowing with milk and honey, here, now.

Evangelists of what?....

The multitudes of men

that Kill the single man, starvations head

One man, their bread and their remembered wine.

Wallace Stevens, "Extracts from Addresses to the Academy of Fine Ideas"

For my son Noah Anthony.

Liberal and Media Studies, Conestoga College Institute of Technology and Advanced Learning, Canada

\section{References}

Beckett, Samuel, The Unnamable (Into the Silence), in The Norton Anthology of English Literature, ed. by M.H. Abrams et. al. (New York: Norton, 1962).

Derrida, Jacques, "A Certain Impossible Possibility of Saying the Event," trans. by Gila Walker, in Critical Inquiry, 33 (Winter 2007).

, "Countersignatures," trans. by Mairéad Hanrahan, in Genet, Special Issue, Paragraph, 27:2 (2004),7-42.

, "Justices," in Critical Inquiry, 31 (Spring 2005).

"On the Priceless," in Negotiations, ed. and trans. by Elizabeth

Rottenburg (Stanford: Stanford University Press).

"Sauf le Nom," in On the Name, trans. by David Wood, et al, (Stanford: Stanford University Press, 1995).

, "Uninterrupted Dialogue: Between Two Infinities, The Poem,"

in Research in Phenomenology, 34 (2004), 3-19.

Glas, trans. by John P. Leavey, Jr. and Richard Rand (Lincoln:

University of Nebraska Press, 1986).

Signsponge, trans. by Richard Rand (New York: Columbia

University Press, 1984).

Hopkins, Gerard Manley, The Poems and Prose of Gerard Manley Hopkins, ed. by

W. H. Gardner (New York, Penguin, 1953).

Hughes, Ted, Birthday Letters (London: faber and faber, 1998).

Kierkegaard, Soren, Works of Love, trans. by Howard and Edna Hong (New York: Harper, 1962).

Leibniz, G.W.F., Philosophical Writings, ed. by G.H.R. Parkinson (London: Dent, 1987).

Strawson, P.F., Individuals: An Essay in Descriptive Metaphysics (London: Methuen, 1959). 


\section{DERRIDA'S TURN}

\section{Appendix}

Reproduction of Andres Serrano's photograph entitled "Piss Christ"

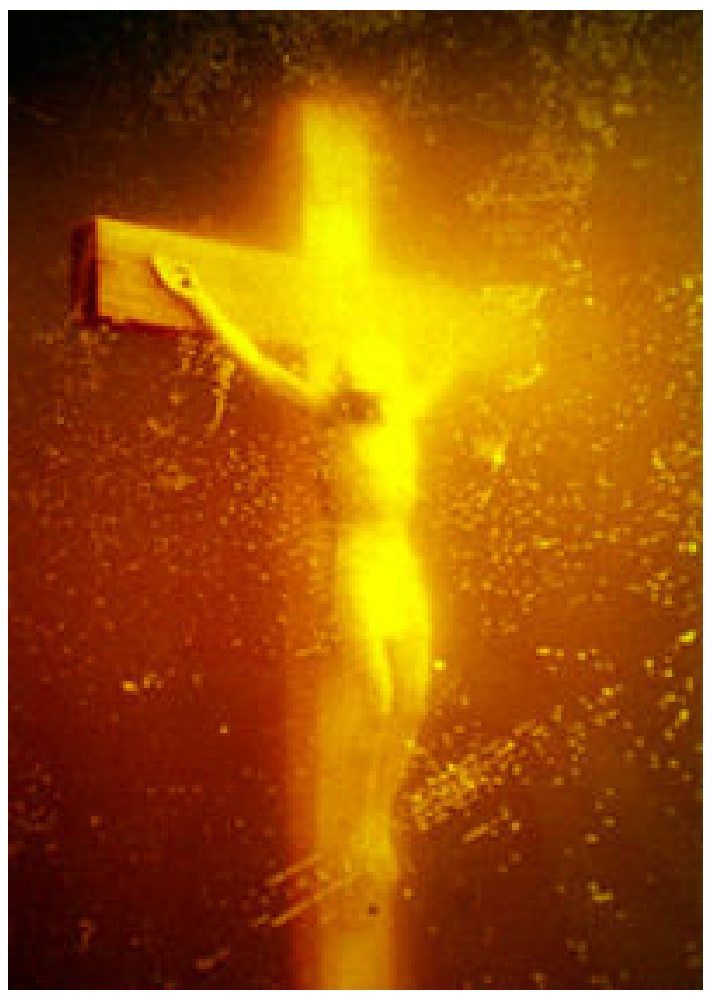

